\title{
APPLICATION OF PROCESS MINING ON THE EXAMPLE OF AN AUTHORIZED PASSENGER CAR SERVICE STATION IN POLAND
}

\author{
Agnieszka BITKOWSKA*, Piotr SLIZ̈**, Candace TENBRINK***, Aleksandra PIASECKA**** \\ *Warsaw University of Technology, Faculty of Management, Warsaw, POLAND \\ e-mail: agnieszka.bitkowska@pw.edu.pl \\ **University of Gdansk, Faculty of Management, Sopot, POLAND \\ e-mail: piotr.sliz@ug.edu.pl \\ ***University of Houston-Downtown, Management, Houston, Texas, UNITED STATES OF AMERICA \\ e-mail: TenBrinkC@uhd.edu \\ ****Hamburg, GERMANY \\ e-mail: piasecka.ola@gmail.com
}

\begin{abstract}
Developing new technologies pose challenges for modern organizations, including service organizations. The main goal of the article was to present the results of exploration of the passenger car repair process using the Celonis Snap program in the example of an authorized service station. Realization of the main goal was assigned to a partial goal, which was to approximate and present the existing state of knowledge regarding process mining. The following research methods were used in the research procedure: systematic review of the literature on the subject and participant observation. Process mining was performed using the Celonis Snap program. The first section of the article, which is of epistemological character, presents the assumptions of process mining. The next one characterizes the empirical structure of the organization under study and the data generated in it. In the following sections, the course of the exploration process of the repair process, results and directions of further research are presented.
\end{abstract}

Keywords: business process, process maturity, process mining, process discovery, after-sales, automotive.

JEL Classification: L620, L250, L840.

\section{Introduction}

The development of business process management is a response to a myriad of factors. Some of the key factors include an increase in the complexity of internal and external processes, the rise of balancing individualization with customer expectations, and demand for shorter product life cycles (Grajewski, 2012; Grajewski, 2007; Gierszewska, 2020; Rosemann and vom Brocke, 2010; Andreeva and Kianto, 2011; Jeston and Nelis, 2014).

In addition, the increase in the emphasis of leveraging knowledge to build dynamic capacity is important. Organizations that want to enhance performance may look to augment the traditional roles of strategy with functional change. In terms of process improvement, firms are blending classic and agile project management processes while hoping to create advantages from intangible assets (Wyrozębski, 2014; Jugdev and Mathur, 2006; Morawski, 2020).
New directions in business process management include inspecting process variability and configuration, the quality of process models, and process mining methods (i.e., automatic detection, compliance checking, performance search, extraction of variants and variants, operational support) (Hawrysz, 2020; Ho, Hsieh and Hung, 2014; Malinova and Mendling, 2018).

The integration of high-quality process data is important for the organization and for the evolution of its process architecture. The TechTrends report (2019) indicates many issues that will affect the implementation of business processes and the functioning of enterprises. These variables incorporate such worldwide issues as the reengineering of new service delivery models (cooperation between people and machines, the no-collar work force), providing data quality management, enabling block chain enterprise data sovereignty, new digital reality, and the interfaces 
for communication between IT systems (Deloitte, 2018).

Knowledge management within enterprise solutions focus on data storage, and the processing and preservation of data as it supports functional processes (Linderman, Schroeder and Sanders, 2010; Paschek, et al., 2018, Rostek, et al., 2012), the use and importance of experts (Patalas-Maliszewska and Krebs, 2018), and the process of collecting data that may be used in conjunction with building business knowledge (Han, Lee and Kim, 2017) to name several areas.

Given the broad need for change and the escalation of technology needs, we focus on business process mining. At the cross section of data analytics and organizational improvement, process mining may be used for a plethora of processes such as the ability to detect deviance, compliance rates, and operational weaknesses (e.g., Process Mining Manifesto, BecerraGarcía, et al., 2017; Fabisz and Sokołowska, 2015; Madison, 2005).

In this study, we offer an example of how one service organization uses process mining. This firm is a manufacturer-authorized automotive repair organization in Poland. We selected Poland as it is a country that has recently experienced many shifts in terms of resource capacity, capabilities and economic growth (e.g., United Nations Development Programme, 2019; World Bank). Thus, it represents a market that continues its trajectory with international competition in the midst of strong economic growth.

\section{$2 \quad$ Assumptions of process mining}

Skillful use and analysis of data improve the organization of enterprises and may allow them to gain a competitive advantage in the market. A critical component to successful process mining is measuring large data sets. The ability to have adequate data will help the management team or process owner to uncover and implement appropriate management and operational processes.

Process mining is a relatively new field of knowledge for practitioners even though academic researchers have been studying it much longer. Process mining relies on digitized business records in an IT system that can enable the construction of process models (van der Alst, et al., 2014; Kantardzic, 2011).

Process mining is an important bridge between data mining and business process modeling. A key component to utilizing process mining is the ability to access the event logs of specific business applications. In many cases, it is often implemented as part of several applications, so it is necessary to reach for all the IT tools used in this process and to merge the distributed data (Sliż, 2019; Suzhen, 2018; Tan, et al., 2006; van Dongen, 2005). What's more, information from business application logs, such as: start time, end time, and resource use allows for in-depth analysis of a given process, for example, in terms of performance.

Process mining covers the following areas of application, which often include:

- Discovery - a procedure where the event log is downloaded and a model is generated using process search algorithms,

- Conformance - a step that compares event logs (real processes) and their corresponding previously developed process reference models (e.g., created BPMN) to identify differences and diagnose deviations or inefficiencies between the actual process and the reference process,

- Enhancement - an outcome of improving reference process models after the data is analyzed.

One main challenge in the study of and the deployment of process mining is to have application software (e.g., DISCO, Celonis Snap, Minit, ProcessGolf and ARIS Process Mining) that will provide access to the appropriate quality of data, because in many cases, the data is incomplete or error-prone. Despite many of these obstacles, there has been a rise in the number of enterprises that implement these process mining driven efficiency solutions. Some of them attempt to combine process mining tools with RPA (robotic process automation) tools.

Thanks to such solutions, it will be possible to obtain data from the actual course of processes. In addition, current process mining tools allow organizations to analyze business processes in real time, which also allows them to monitor the implementation of processes using RPA solutions. 


\section{Assumptions for ongoing research - research proceedings}

The analyzed company is an authorized automotive service station located in Poland and operating in the SME sector. The organization's main activity is focused on the implementation of two mega processes: sales of new and used cars, and after-sales customer service. The organization in our study has a license to implement both of these processes for two premium automotive brands.

The enterprise in this study was classified as a process organization via an opinion survey and the multicriteria model of process maturity assessment (Sliż, 2018a; Sliż, 2018b), at the third level of process maturity. This means that the state of the system has been confirmed, in which the organization consciously understands the benefits of identifying, formalizing and measuring processes.

In accordance with the process assessment assumptions, it appears that these organizations may be able to reach the fourth level of process maturity.

The data for this study was gathered in 2019 for 193 completed passenger automotive repairs. The selection criterion was determined by the types of repairs carried out and the period of their implementation being examined. Paid and warranty repairs carried out in the third quarter of 2018 were studied to understand the process flow in the empirical proceedings.

Based on the available technical and workshop documentation, the organization's manual records of process executors were digitized and a relational database was designed that included detailed event-logs.

The analysis included 193 process cases and 1100 events corresponding to the automobile undergoing repairs (bodywork and paint repairs were not included in the study). The acquired data were processed and implemented into a program that allows exploration using the Celonis Snap process.

\section{Discussion of research and results}

The first step in the evaluation was to identify the socalled happy path (Figs. 1-2).

This sequence of events illustrates the most common sequence of events within the examined business process. The happy path in this process was:

- registration for the service (service reception),

- start of repair,

- end of repair,

- deregistration from the site (service reception check out),

- invoicing.

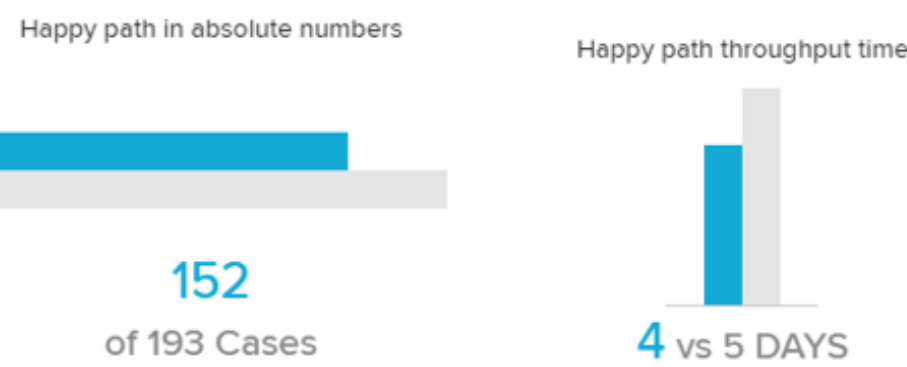

Algorithmic happy path

Service reception

Start of repair

End of repair

Service reception (check-out)

Invoicing
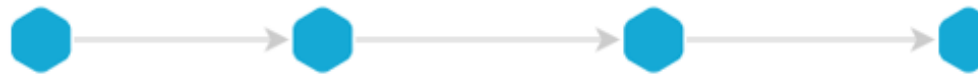

Figure 1. Happy path characteristics in the after-sales service process

(Source: Own study based on Celonis Snap) 
As a result of the initial analysis, it was estimated that $78.8 \%$ of the examined repair cases were carried out according to the indicated sequence of events, which suggest high uniformity in the examined business process (Fig. 1).The analysis shows a mean throughput time of 4 days for the happy path versus 5 days for the entire group of 1100 events studied in the 193 cases.

The course of the most frequently occurring sequence of events is shown in Fig. 2.

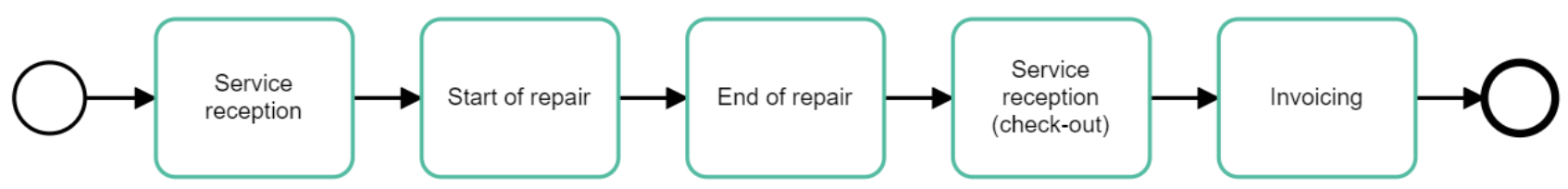

Figure 2. Reference model of the examined after-sales service process

(Source: Own study based on Celonis Snap)

Our study found 14 cases that followed a different sequence of events for 41 repair requests, which indicates strong fragmentation in this group (Fig. 3).
One of the reasons for the fragmentation is due to deficiencies or irregularities related to the recording of the time the repair by the process implementer. As Fig. 4 indicates, there were 3 instances of each deviation in the subprocess.

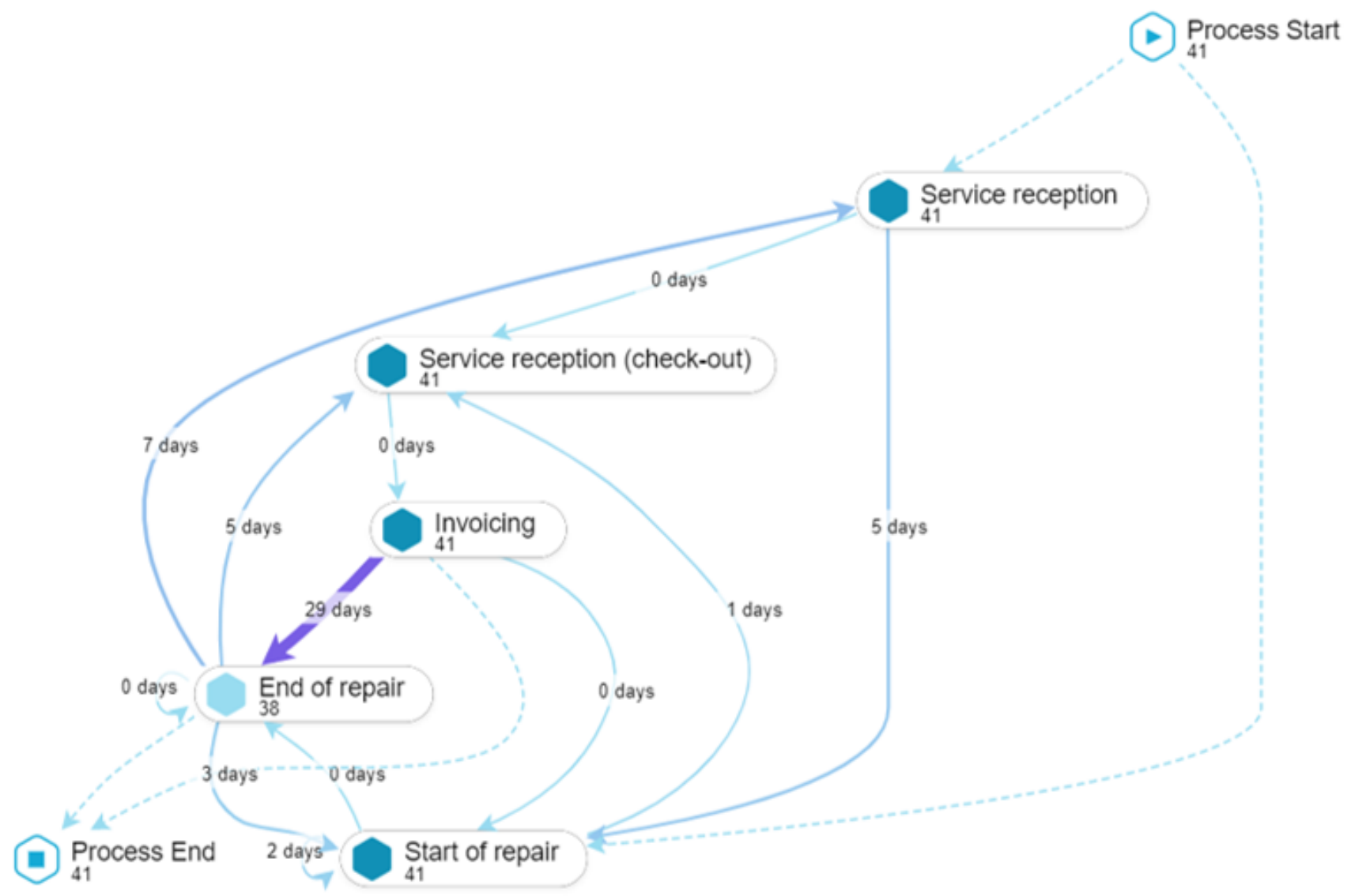

Figure 3. Characteristics of 14 irregular cases (Source: Own study based on Celonis Snap) 


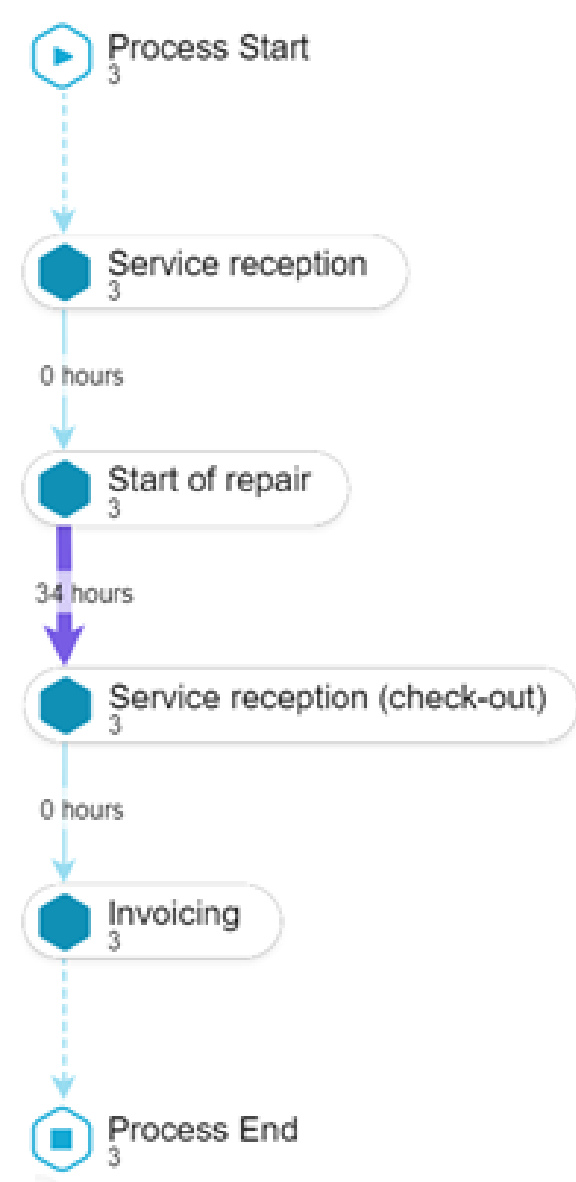

Figure 4. Characteristics of 3 variant cases (Source: Own study based on Celonis Snap)

Fig. 5 shows the characteristics of the duration of the described process. Noteworthy is the identified difference between the median duration of the full process (6 days) and its average (1 day). This may indicate that there are outliers characterized by particularly long process times - as exemplified by the lengthy process run lasting 42 days (Fig. 5).

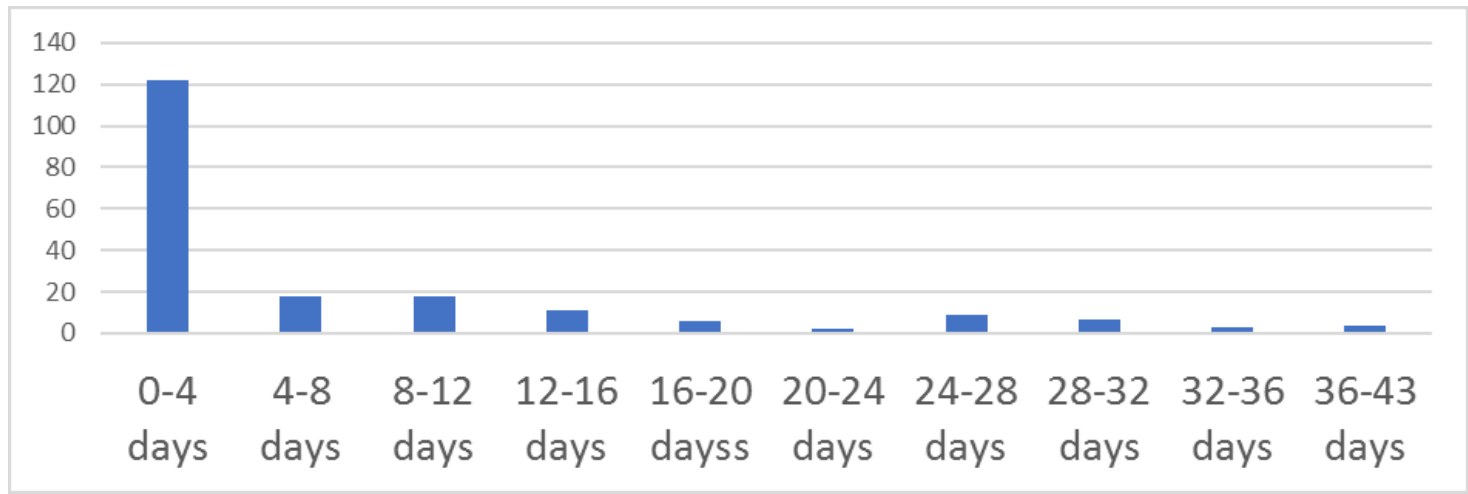

Figure 5. Implementation times of each stage (Source: Own study based on Celonis Snap) 
The majority $(63 \%)$ of the cases were implemented within 4 business days. However, in $25 \%$ of the cases, the repair process took a minimum of 10 days. This extended the median time to 17 days. Fig. 6, identifies the average and median throughput times for the major sub-process in this study.
For example, the time between leaving the automobile at the service center and starting the repair, took an average of 2.5 days, although the median repairs started almost immediately. These data are skewed by $10 \%$ of the cases that had a wait time of 10 days or longer for the repairs to begin.

\section{Throughput Time per Connection}

\begin{tabular}{|c|c|c|c|c|}
\hline Source & Target & \# Occurences $\downarrow \bar{Z}_{1}$ & $\begin{array}{l}\text { Median } \\
\text { Total throughput time }\end{array}$ & $\begin{array}{l}\text { AVG } \\
\text { Throughput time }\end{array}$ \\
\hline Start of repair & End of repair & 256 & 0.06 days & 0.08 days \\
\hline Service reception (check-out) & Invoicing & 193 & 0.00 days & 0.14 days \\
\hline Service reception & Start of repair & 192 & 0.00 days & 2.46 days \\
\hline End of repair & Service reception (check-out) & 187 & 0.61 days & 2.83 days \\
\hline End of repair & Start of repair & 66 & 0.91 days & 3.21 days \\
\hline Start of repair & Service reception (check-out) & 5 & 0.65 days & 1.10 days \\
\hline Start of repair & Start of repair & 4 & 0.98 days & 2.28 days \\
\hline End of repair & Service reception & 2 & 12.55 days & 6.95 days \\
\hline End of repair & End of repair & 2 & 0.06 days & 0.05 days \\
\hline Invoicing & End of repair & 1 & 29.42 days & 29.42 days \\
\hline Invoicing & Start of repair & 1 & 0.47 days & 0.47 days \\
\hline Service reception & Service reception (check-out) & 1 & 0.00 days & 0.00 days \\
\hline
\end{tabular}

Figure 6. Summary statistics on the process flow between the identified stages (Source: Own study based on Celonis Snap)

Another important aspect of the process under review is the final stage, the time from repair completion to deregistration from the site. On average, this took 2.8 days. In more than $16 \%$ of cases, it took a minimum of 5 days. This gap in pick up may negatively impact the servicing of other cars, when space for storage is a full repair (Fig. 6). These extended stages of the process, the so-called bottlenecks, extend the duration of the entire process. While these bottlenecks are typically subjective and prone to assessment error in traditional forms of process analysis, process mining may be used to monitor these directly.
Next, an attempt was made to analyze, repair times in relation to two variables considered in the study: the type of repair, the model of the repaired car and the employee carrying out the repair. Despite the small data set in this empirical investigation, the relationships between the indicated variables are possible to investigate.

In the surveyed organization, warranty repairs, constituting $34 \%$ of all repairs, have an almost twice as long average lead time as non-warranty repairs (11.96 days versus 5.05 days).

\section{Throughput Time per repair type}

\begin{tabular}{l|r|r|r}
\hline Repair type & \# Occurences & Median Total throughput time ... $\Xi_{1}$ & AVG Throughput time \\
\hline WARRANTY & 66 & 9.00 days & 11.96 days \\
\hline NON WARRANTY & 127 & $\mathbf{0 . 0 0}$ days & $\mathbf{5 . 0 5}$ days \\
\hline
\end{tabular}

Figure 7. Characteristics of the process lead time by repair type (Source: Own study based on Celonis Snap) 
Fig. 7 presents detailed statistics on the implementation of two types of repairs (warranty and non-warranty). The median duration of the process is 15 hours for non-warranty repairs and 167 hours for warranty repairs. These discrepancies are also confirmed by arithmetic averages of 113 and 260 hours, respectively. In addition, for warranty repairs, these are process sections between admission to the service and the beginning of the repair - median $=32$ hours, and between the end of the repair and re-registration of the service - median $=58$ hours.

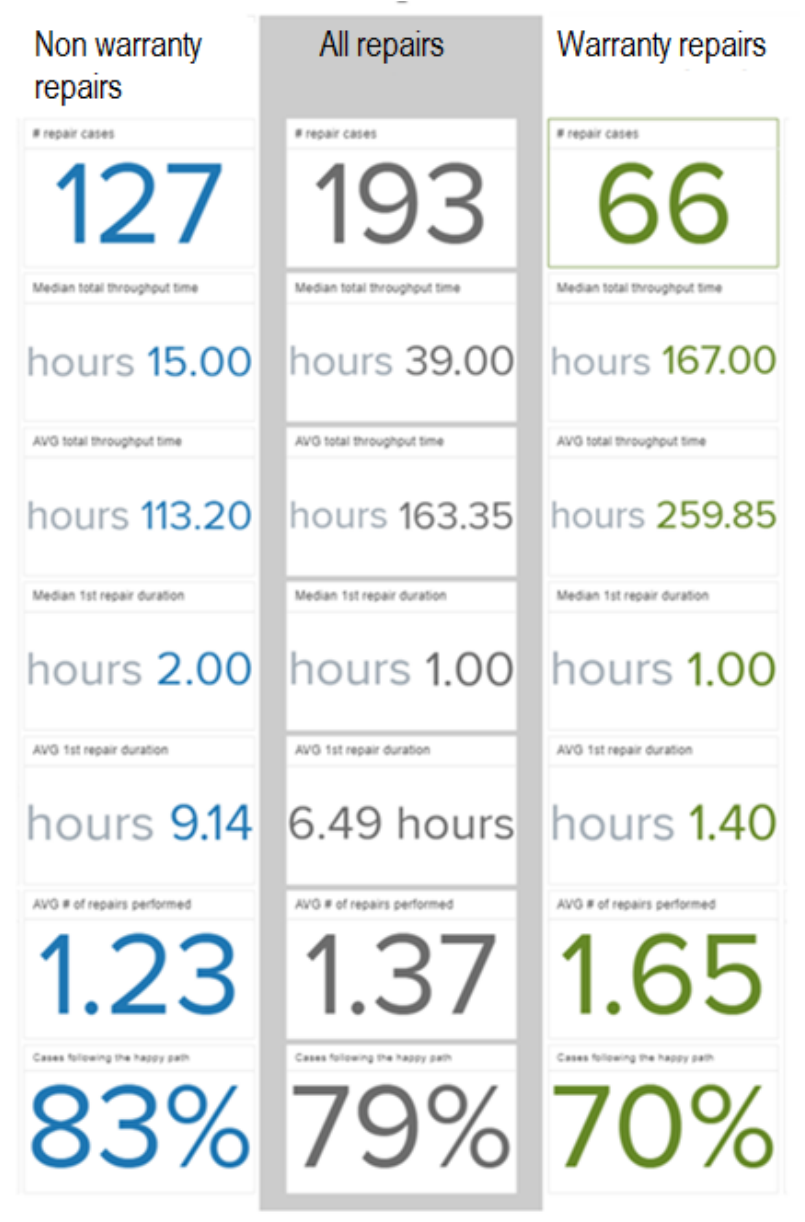

Figure 8. Characteristics of the process by type of repair carried out (Source: Own study based on Celonis Snap)

Fig. 8 shows some loops between the end and start of the repair events; this indicates multiple repairs within one repair order. Please note that the next repair starts 24 hours after the previous one has ended for non-warranty repairs (median) and 17 hours for warranty repairs.

This time depends on the availability and number of parts necessary to complete the repair. In the absence of parts in the dealership's warehouse, they are ordered from the importer or manufacturer. Additionally, an increase in repairs per order leads to an increase in time.

As can be seen in Fig. 8, this is an average of 1.65 repairs during servicing for warranty and 1.23 for paid repairs. The bar charts in Fig. 8 show in detail the distribution of repair orders, unit repairs and process times. In the case of a warranty, multiple repairs take place more often. Because each repair requires additional time (both active and passive), the total service time increases. 


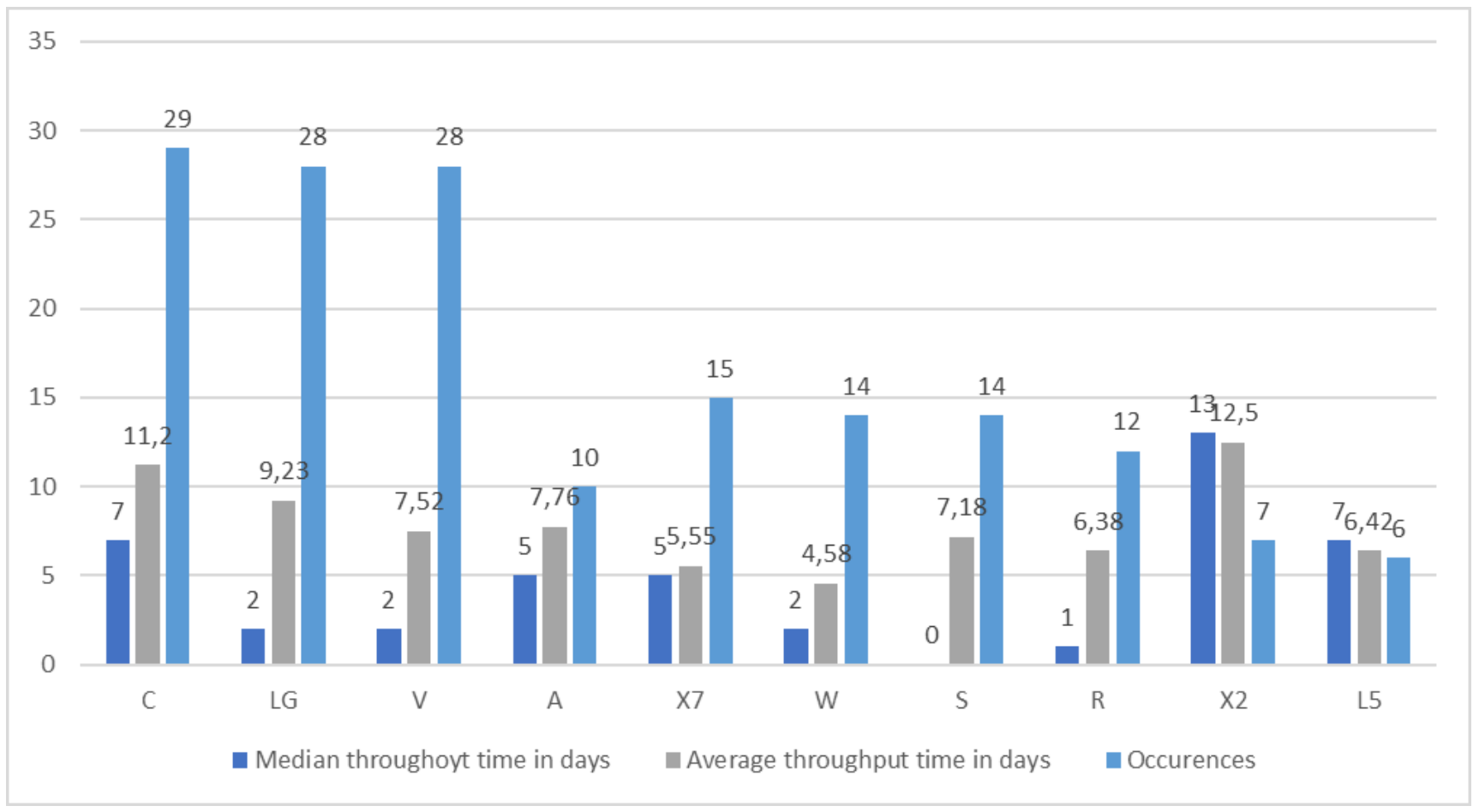

Figure 9. Characteristics of the time of the process implementation due to the car model (Source: Own study based on Celonis Snap)

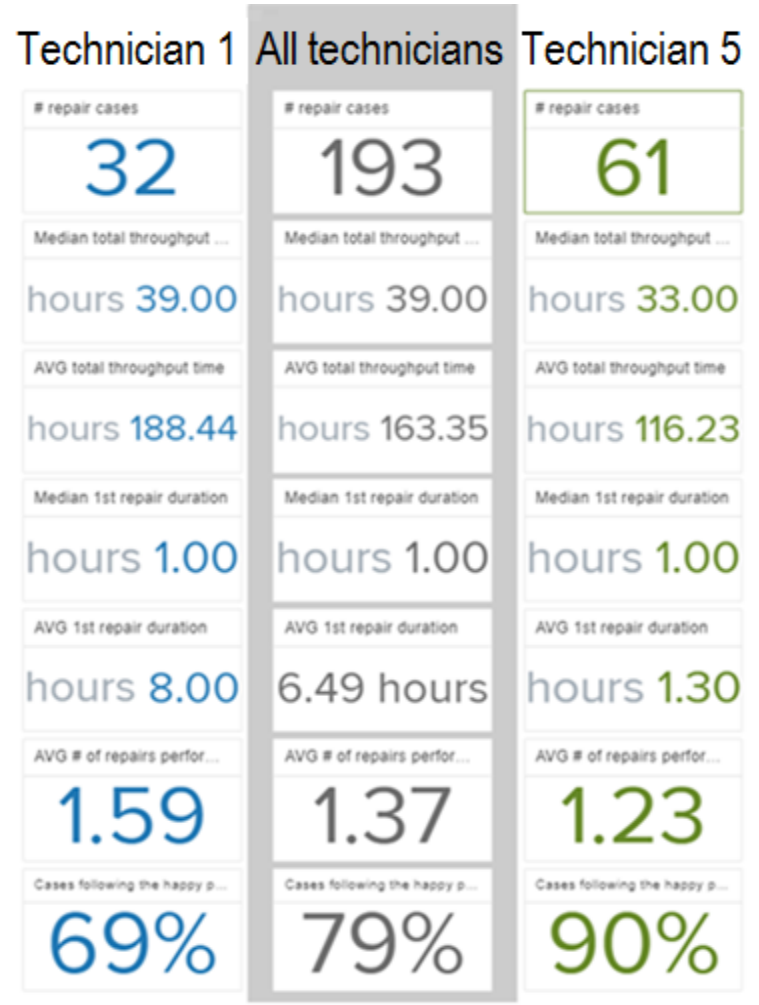

Figure 10. Characteristics of the process under examination due to the process executor (technician 1 versus technician 5) (Source: Own study based on Celonis Snap) 
Analyzing the course of the process due to the model of the repaired vehicle, it was noticed that the service times of individual models differ significantly from each other.

For the most prevalent model, identified as C (29 repairs), the total flow time took 11.25 days on average (median 7 days), while model $\mathrm{W}$ required less than half of that time (average 4.58 days, median 2 days)

In Fig. 10, we show that a process mining analysis may offer an organization the ability to make databased decisions. The data indicates which repairs are the most time consuming and the most efficient in terms of variance analysis. For example, even though the average duration of the repair process took 163 hours, it varied widely between technicians.

The deviance between technician 1 and 5 was 72 hours. Upon closer inspection, technician 1 appears to have more time consuming repairs as his/her repair duration was 8 hours for 32 repairs versus 1.3 hours for 61 repairs by technician 5 . It could be that technician 1 is in training, inefficient, or perhaps more qualified to complete more nuanced repairs.

The output from the process mining enables management not only to inspect these differences, but also to track them over time. Given the previously identified "happy path" (Fig. 2), the analysis indicated that technician 5 followed this sequence in $90 \%$ of the cases while technician 1 followed it in $69 \%$ of the cases.

\section{Conclusion}

Process mining is a challenge for many processes-oriented organizations. The exploration of processes in this study enabled the identification and formalization of the actual course of the audited process based on the collected data recorded as part of after-sales customer service activities and activities related to diagnosis, repair, and quality control. In this section we offer conclusions and directions for future research.

- First, in the example of the examined organization classified at the third level of process maturity, it is possible to implement process-mining solutions. This means that the analysis can be carried out in a state in which the process is measured, and event times recorded using work-time record- ers and manual records implemented by the process implementers (in this case, service consultants and workshop employees).

- Second, the implementation of the process-mining method and dynamic assessment of the implemented after-sales process enabled the management and optimization of processes, thus achieving the fourth level of process maturity according to the organization that adopted the MMPM assessment methodology.

- Third, the possibility of obtaining benefits resulting from the use of process-mining in the examined organization may be combined with further data to deepen its analysis. Process mining can affect future actions by improving the quality of data generated in the organization and introducing methods to verify the data quality.

We offer directions for future research. While this study was conducted in Northern Poland, it could be expanded to more regions not only in Poland but also in similar transitional areas.

One limitation of this study is the use of a non-probabilistic selection for the test sample, which limits the conclusions to 193 completed repairs. Therefore, a larger study may provide further insights.

Research in the after-sales car market remains limited; literature on original equipment manufacturers is more prevalent than services. As such, studies that add to the process capabilities and competitive process of after-sales markets are needed.

Process research that adds understanding to when and how management teams embrace process mining would be especially relevant for scholars and practitioners.

\section{References}

[1] Becerra-García, R.A., García-Bermúdez, R.V., Joya-Caparrós, G., Fernández-Higuera, A., Velázquez-Rodríguez, C., Velázquez-Mariño, M., Cuevas-Beltrán, F.R., García- Lagos, F. and Rodráguez-Labrada, R., 2017. Data Mining Process for Identification of Non-Spontaneous Saccadic Movements in Clinical Electrooculography. Neurocomputing, 250, pp.28-36. 
[2] Berry, M.J.A., Linoff, G.S., 2000. Mastering Data Mining. New York: Wiley.

[3] Besheli, P.R., Zare, M., Umali, R.R., Nakhaeezadeh, G., 2015. Zoning Iran Based on Earthquake Precursor Importance and Introducing a Main Zone Using a Data-mining Process. Natural Hazards, 78(2), pp.821-835.

[4] Bitkowska, A., 2019. Od klasycznego do zintegrowanego zarzadzania procesowego (From Classical to Integrated Process Management). Warsaw: CH Beck.

[5] Czubasiewicz, H., Grajewski, P., Sliż, P., 2018. Dojrzałość procesowa hoteli i obiektów noclegowych w Polsce - wyniki badania empirycznego (Process Maturity of Hotels and Accommodation Facilities in Poland - the Results of the Empirical Study). Scientific Journals of Poznan University of Technology, 76, pp.243-257.

[6] Deolitte. Tech Trends 2019 Beyond the Digitial Frontier. [online] Available at: https://www2. deloitte.com/content/dam/Deloitte/br/Docume nts/technology/DI_TechTrends2019.pdf [Accessed 16 March 2020].

[7] Fabisz, K., Sokołowska, W., 2015. Techniques of Exploring Business Processes as a Source of Gaining Competitive Advantage for Dynamically Developing Enterprises. Economic Studies, 243, pp.67-79.

[8] Gierszewska G. (ed.), 2020. Zarządzanie w przedsiębiorstwie N.O. Droga do przyszłości (Enterprise Management N.O. Road to the Future), Warsaw University of Technology Publisher, pp.23-42.

[9] Grajewski, P., 2007. Organizacja procesowa (Process Organization). Warsaw: PWE.

[10] Grajewski, P., 2012. Zarządzanie organizacja procesowa (Process Management of an Organization). Warsaw: PWE.

[11] Han, J., Pei, J., Kamber, M., 2011. Data Mining: Concepts and Techniques. Elsevier, United States of America.

[12] Han, J., Lee, S. and Kim, J.K., 2017. A Process Integrated Engineering Knowledge Acquisition and Management Model for a Project Based Manufacturing. International Journal of Precision Engineering and Manufacturing, 18, pp.175-185.
[13] Handzic, M., 2017. The KM Times They Are AChangin'. Journal of Entrepreneurship, Management and Innovation, 13 (3), pp.7-28.

[14] Hawrysz, L., 2020. Koncepcja zdolności dynamicznych jako odpowiedź na zmiany zachodzące na rynku (The Concept of Dynamic Abilities as a Response to Market Changes). In: G. Gierszewska (ed.), 2020. Zarzadzanie w przedsiębiorstwie N.0. Droga do przyszłości (Management in the Enterprise N.O. Road to the Future). Oficyna Wydawnicza Politechniki Warszawskiej: Warsaw, pp.189-201.

[15] Ho, C.F., Hsieh, P.H., Hung, W.H., 2014. Enablers and Processes for Effective Knowledge Management. Industrial Management \& Data Systems, 114(5), pp.734-754.

[16] Jeston, J., Nelis, J., 2014. Business Process Management. Routledge, Taylor \& Francis Group, London and New York.

[17] Jugdev, K., Mathur, G., 2006. A Factor Analysis of Tangible and Intangible Project Management Assets. In: 4th Project Management Research Conference.Montréal, Québec, Canada. 2006. PA: Project Management Institute.

[18] Kantardzic, M., 2011. Data Mining: Concepts, Models, Methods, and Algorithms. John Wiley \& Sons.

[19] Ko, R.K., Lee, S.S., Lee, E.W., 2009. Business Process Management (BPM) Standards: a Survey. Business Process Management Journal, 15(5), pp.744-791.

[20] Linderman, K., Schroeder, R.G., Sanders, J., 2010. A Knowledge Framework Underlying Process Management. Decision Sciences, 41(4), pp.689-719.

[21] Ltifi, H., Benmohamed, E., Kolski, C., Ayed, M.B., 2016. Enhanced Visual Data Mining Process for Dynamic Decision-Making. KnowledgeBased Systems, 112, pp.166-181.

[22] Madison, D., 2005. Process Mapping, Process Improvement, and Process Management: a Practical Guide for Enhancing Work and Information Flow. Chico: Paton Professional. 
[23] Malinova, M., Mendling, J., 2018. Identifying Do's and Don'ts Using the Integrated Business Process Management Framework. Business Process Management Journal, 24(4), pp.882-899.

[24] Martín-de Castro, G., López-Sáez, P., DelgadoVerde, M., Andreeva, T., Kianto, A., 2011. Knowledge Processes, Knowledge - Intensity and Innovation: a Moderated Mediation Analysis. Journal of Knowledge Management, 15 (6), pp.871-874.

[25] Martínez-Martínez, A., Suárez, L.M.C., Montero, R.S., del Arco, E.A., 2018. Knowledge Management as a Tool for Improving Business Processes: an Action Research Approach. Journal of Industrial Engineering and Management, 11(2), pp.276-289.

[26] Medvedev, V., Kurasova, O., Bernatavičienė, J., Treigys, P., Marcinkevičius, V., Dzemyda, G., 2017. A New Web-based Solution for Modeling Data Mining Processes. Simulation Modeling Practice and Theory, 76, pp.34-46.

[27] Morawski, M., 2020. Zarządzanie wiedzą jako nowy paradygmat $\mathrm{w}$ gospodarce 4.0. (Knowledge Management as a New Paradigm in the Economy 4.0.). In: G. Gierszewska, ed., 2020. Zarzadzanie w przedsiębiorstwie N.O. Droga do przysztości (Management in the Enterprise N.O. Road to the Future). Oficyna Wydawnicza Politechniki Warszawskiej: Warszawa, pp.23-42.

[28] Patalas-Maliszewska, J., Krebs, I., 2018. An Information System Supporting the Eliciting of Expert Knowledge for Successful IT Projects. In: Damaševičius R., Vasiljevienė G. (eds). Information and Software Technologies. ICIST 2018. Communications in Computer and Information Science, Vol. 920. Springer, Cham.

[29] Paschek, D., Ivascu, L., Draghici, A., 2018. Knowledge Management - The Foundation for a Successful Business Process Management. Procedia-Social and Behavioral Sciences, 238, pp.182-191.

[30] Pechenizkiy, M., Puuronen, S., Tsymbal, A., 2005. Why Data Mining Research Does not Contribute to Business ? In: Proc. Of Data Mining for Business Workshop DMBiz (ECML / PKDD'05). Porto, Portugal, pp.67-71.
[31] Robonomika.pl. [online] Available at:. https://robonomika.pl/process-mining-doskonale -uzupelnienie-robotic-process-automation-robo tyzacji-procesow-biznesowych [Accessed 10 October 2019].

[32] Rosemann, M., vom Brocke, J., 2015. The Six Core Elements of Business Process Management. In: Handbook on Business Process Management 1, Berlin: Springer, pp.107-122.

[33] Rostek, K., Wiśniewski, M. and Kucharska, A., 2012. Cloud Business Intelligence for SMEs Consortium. Foundations of Management, 4(1), pp.105-122.

[34] Rosemann, M., vom Brocke, J., 2015. The Six Core Elements of Business Process Management. In: Handbook on Business Process Management 1. Berlin: Springer, pp.107-122.

[35] Sliż, P., 2018a. Concept of the Organization Process Maturity Assessment. Journal of Economics \& Management, 33, pp.80-95.

[36] Sliż, P., 2018b. Process Maturity of Contemporary Organizations in Poland. Sopot: University of Gdańsk Publishing House.

[37] Sliż, P., 2019. Data Mining Process Maturity Result of Empirical Research. Management Problems, 2(82), pp.233-251.

[38] Steven, E.J., 2019. Integrating Knowledge Management and Business Processes. Advanced Methodologies and Technologies in Library Science. Information Management, and Scholarly Inquiry, pp.356-366.

[39] Suzhen, Q., 2018. Data Mining and Business Process Management of Apriori Algorithm. In: IOP Conference Series: Materials Science and Engineering, IOP Publishing.

[40] Tan, P.N., Steinbach, M., Kumar, V., 2006. Introduction to Data Mining, New Delhi: Pearson Education. Inc.

[41] The World Bank. [online] Available at: https://www.worldbank.org/en/country/poland/ overview [Accessed 16 March 2020].

[42] United Nations Development Programme, 2019. Human Development Index Rating. [online] Available at: http:/hdr.undp.org/en/content/2019-human-development-index-ranking [Accessed 1 February 2002]. 
[43] Wyrozębski, P., 2014. Zarzadzanie wiedza projektowa (Project Knowledge Management). Warsaw: Difin.

[44] van der Aalst, W.M.P., 2009. Process Mining Manifesto. IEEE Task Force for Process Mining.
[45] van Dongen, B.F., de Medeiros, A.K.A., Verbeek, H.M.W., Weijters, A.J.M.M., van Der Aalst, W.M., 2005. The ProM framework: A New era in Process Mining Tool Support. In: International Conference on Application and Theory of Petri Nets. Berlin, Heidelberg: Springer, pp.444-454. 